University of Louisville

ThinkIR: The University of Louisville's Institutional Repository

$5-1930$

\title{
Effects of thermal influences upon the pons and medulla and upon the mid brain and diencephalon after ligation of the basilar artery.
}

Franklin Jelsma

University of Louisville

Follow this and additional works at: https://ir.library.louisville.edu/etd

\section{Recommended Citation}

Jelsma, Franklin, "Effects of thermal influences upon the pons and medulla and upon the mid brain and diencephalon after ligation of the basilar artery." (1930). Electronic Theses and Dissertations. Paper 682. https://doi.org/10.18297/etd/682

This Master's Thesis is brought to you for free and open access by ThinkIR: The University of Louisville's Institutional Repository. It has been accepted for inclusion in Electronic Theses and Dissertations by an authorized administrator of ThinkIR: The University of Louisville's Institutional Repository. This title appears here courtesy of the author, who has retained all other copyrights. For more information, please contact thinkir@louisville.edu. 
Introduction $\ldots \ldots \ldots \ldots \ldots \ldots \ldots \ldots \ldots \ldots \ldots \ldots \ldots \ldots \ldots \ldots$

Methods and Apparatus .......................

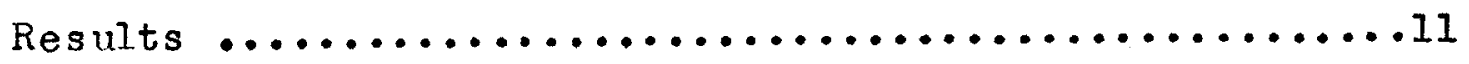

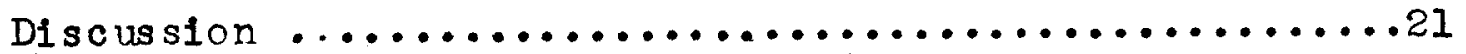

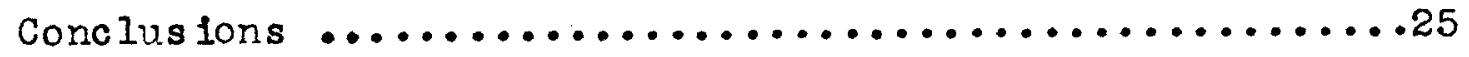

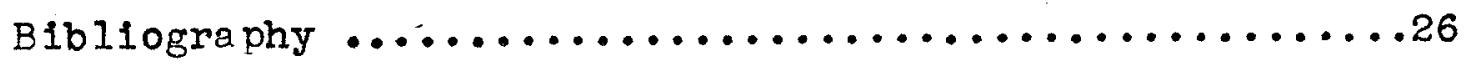


EFFECTS OF THERMAL INFLUENCES UPON THE PONS AND MEDULLA AND UPON THE MID BRAIN AND DIENCEPHALON

AFTER LIGATION OF THE BASIIAR ARTERY

Durirg the past two decades, substantial advances have been made toward the understanding of various phases of heat regulation. Meny threads leading to the explanation of the complete mechanism of heat regulation of the body have been unraveled. Altho the exact anatomical location, extent and relations have not yet been determined, it has become evident that the chief control of body temperature is thrut he central nervous system. Especially important regions are the basal nuclel and the brain stem.

Barbour $_{1}$ has produced evidence, confirmed by. Hashimoto ${ }_{2}$, Prince and Hahn $_{3}$, Rogers, ${ }_{4}$ Bazett and Penfield ${ }_{5}$, that temperature control occurs by means of temperature influences upon the central nervous system as well as indirectly by way of the skin. Altho the heat and cold were applied in the vicinity of the caudate nucleus, they undoubtedly influenced the thammus and hypothalamus, as well as the corpus striatum.

Barbour $_{1}$ in 1921, and Bazett 6 in 1927, reviewed the literature very thoroughly in regard to "The Heat Regulating 
Mechanisms Of The Body", and "Physiological Responses To Heat",Fespectively. From Pembrey ${ }_{7}$, Lefevre 8 and Richet 9 , may be secured references of earlier work. Rogers 4 has investlgated many details of heat regulation upon normal and decerebrated pigeons. Other workers have used all types of animals, many have used varlous degrees of decerebration and of spinal transection; some have made heat punctures, placed tubes within the brain for heating and cooling purposes; some have heated the carotid blood; ail with the idea of solving some phase of heat regulation.

The purpose of the present investigation has been to distingulsh between the effects of verious temperature influences upon the pons and the medulla on the one hand and the mid brain and telencephalon on the other. Heat and cold were applied to these two regions both simultaneously and separately. For the purpose of greater clarity, it was assumed provisionally that, as with living cells in general, he at is essentially a stimulant and cold a depressant of brain centers. By thus stimuleting or depressing the activities of these regions one can estimate the anatomical level at which certain functicnal responses may be secured. Heymans 10 found in dogs that reflexes of the is olated head continued until the subdural temperature reached from $45^{\circ} \mathrm{C}$. to $46^{\circ} \mathrm{C}$., when the brain died. In spinel cats maximum muscular responses are received with a temperature at $38^{\circ} \mathrm{C}$. The brain was divided into the above portions for separate study because it is anatomically and functionally 
suited for division here. Its blood supply is eas1ly separated to correspond and the reby offers a ready method for the conduction of various temperature influences to each part independent of the other as well as avoding the effects of trauma to the immediate brain tissue of these areas .

With the basilar artery ligated at the level of the fifth nerve, the carotid blood carries the various thermal stimuli to the upper portion and the vertebral blood carries the thermal influences to the pons and medulla. Thus, the thermal variations conducted by the carotid blood can be observed independently of, or simultaneously with, the thermal influences conducted by the vertebral blood. The division is in reality only a division of the stimulating or depressing mechanisms. This leaves the brain anatomical ly intact and permits the observation of stimulating and depressing effects upon two portions of a normal functioning brain.

From evidence arrived at upon decerebrate cats, Bazett and Penfield 5 placed the mechanism for temperature control "between the level of the middle of the superior colliculus and $2 \mathrm{~mm}$. In front of the pons and the upper limit of the thalamus." Sherrington 11 thinks that the central localization of the cold shivering mechanism "may correspond with that for general nervous temperature control." Bazett 6 aga in, In 1927, cited Isenschmid and Krehl 12 , Leschke ${ }_{13}$, Isenschmid and Schintzler ${ }_{14}$, de Barenne ${ }_{15}$, and Rogers 4 as considering the "actual position of the center or centers 
controlling the body temperature" to be in the "thalamus, hypo-thalamus or tubercinereum, tho certainly above the level of the pons and medulla." These are found within one upper division and can recelve stimulation or inhibition by way of the carotid blood. The vasomotor and respiratory mechanisms are in the lower portion and can recelve simulation or inhibition by way of the vertebral blood. Muscular activity can be influenced from both regions, as will he discussed below. 


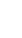

METHODS AND APPARATUS 


\section{METHODS AND APPARATUS}

The preparation of the an imals constituted the preliminary step. Short-haired dogs, of moderate size and with a fairly broad head, were selected. Highly excitable animals were avoided, as the final thermal observations were to be made without narcosis or hypnosis.

The operation for the occlusion of the basilar artery was porformed under ether anesthesia. Under amytal, given intra-peritoneally, several sudden respiratory failures with death were noticed, when the basllar artery was occluded. We do mot know that the anesthetic was the cause of the respiratory failure, yet no such difficulty was encountered under ether anesthesia. Of course another factor contributIng to the fatalities of this procedure is the manipulation of the artery itself. Tension on the basilar artery may cause anemia of the pons and medulla as well as rupture of some of the smaller branches coming from it.

The route for the exposure of the vessels was described by Pollock and $D_{2}$ is ${ }_{16}$ for purposes of destroying the function of centers above this point. The technique used by us, is as follows:-

With the animal under ether and a preliminary of $.5 \mathrm{mg}$. of atropine and no morphine, the mouth is held open wi th a side mouth gag. The tongue is tied over the mandible fairly taut. The soft palate is then injected with normal saline (with 6 drops of adrenalin 1-1000 per oz.) in the mid line to control oozing. The soft tissues of the naso-pharynx 
are likewise injected and incisions made thru both to expose the base of the skull. With the tympanic bullae as bony land marks, a small piece of bone is chiseled out in the mid-line beginning on a line traversing the tympanic bullae thru the middle. A specially adapted rongeur is then used to $r$ emove as much bone as necessary to expose the artery for clipping. The artery can be seen pulsating thru the dura.

The dura is then opened and the spinal fluid removed by suction. A right angle hook with about $2 \mathrm{~mm}$. horizontal length is carefully placed under the artery and silver clips applied. (Three are usually sufficient.) Care must be exercised not to move the vessel to any extent. The soft tis sues are sutured with interrupted catgut. It is well to use a Cushing head light for illuminating purposes.

The anima I is now allowed from one to three weeks for recovery. About twenty-four hours before observations are to be made, the secondary operation is performed. The metal jackets for heating and cooling are placed about the carotid and vertebral arteries.

Light ether anesthesia, or local, can be used. Fortunately the entire procedure can be accomplished thru one mid-line incision, extending well down on the sternum. It is not necessary to transect any of the neck muscles. It is also better to expose the vertebrals at their entrance into the cervical foramen at the sixth cervical vertebra, 
rather than at their origin from the brachial arteries. When both carotid and vertebral arteries are exposed, the jackets are applie d with the slot outward and gauze is packed carefully about them to prevent spread of temperatureinfluences to the adjacent structures, particularly to the vagus nerves. The tubings leading to and from these jackets are especially insulated. The next day the animal is ready for study.

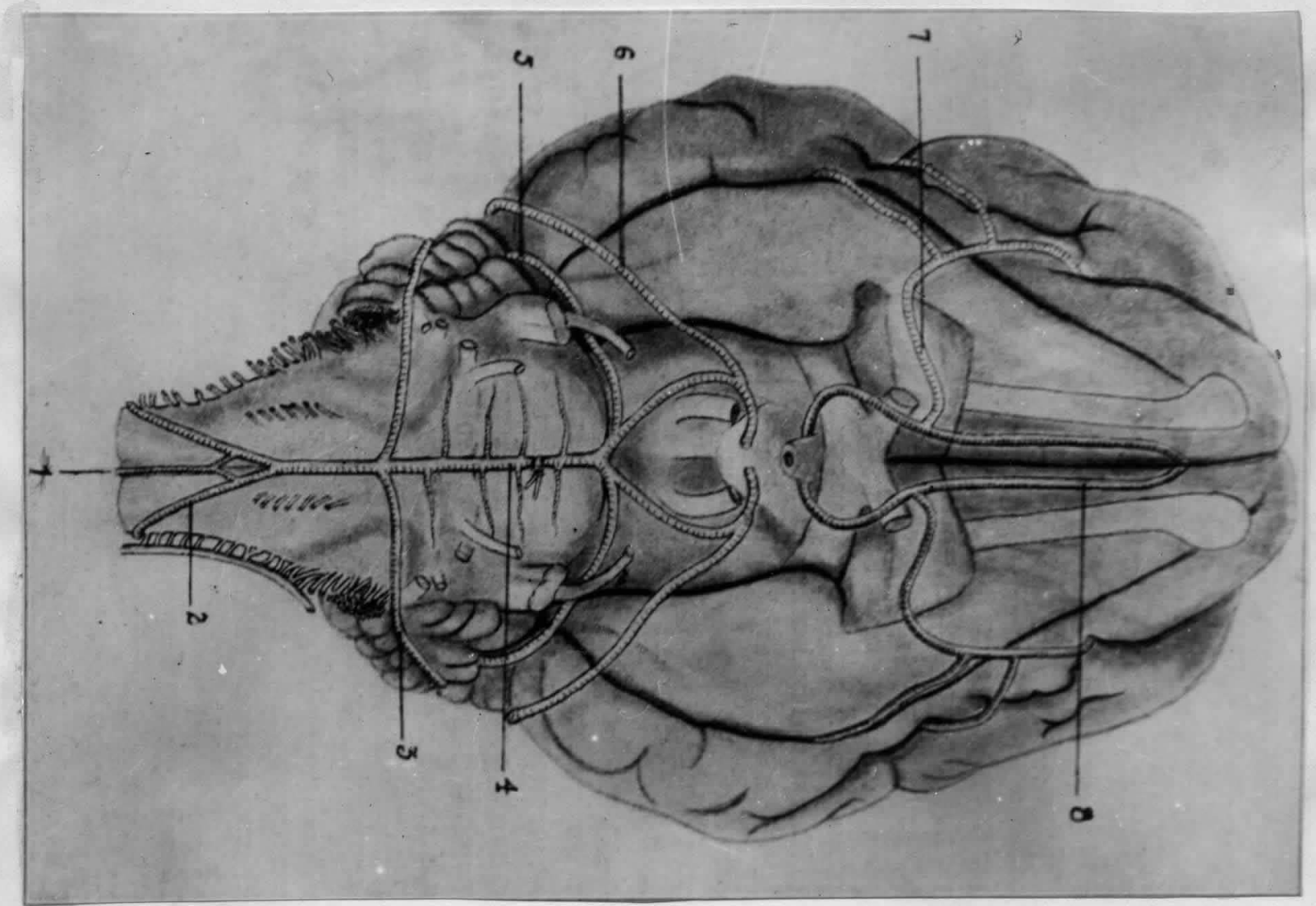

Figure I.

(Pollock and Davis 16 ) Base of brain showing point of ligation of basilar artery: 2 - Vertebral artery; 3 - posterior inferior cerebellar artery; 4 - basilar artery; 5 - posterior superior cerebellar artery; 6 - posterior cerebral artery; 7 - middle cerebral artery; 8 - anterior cerebral artery. 


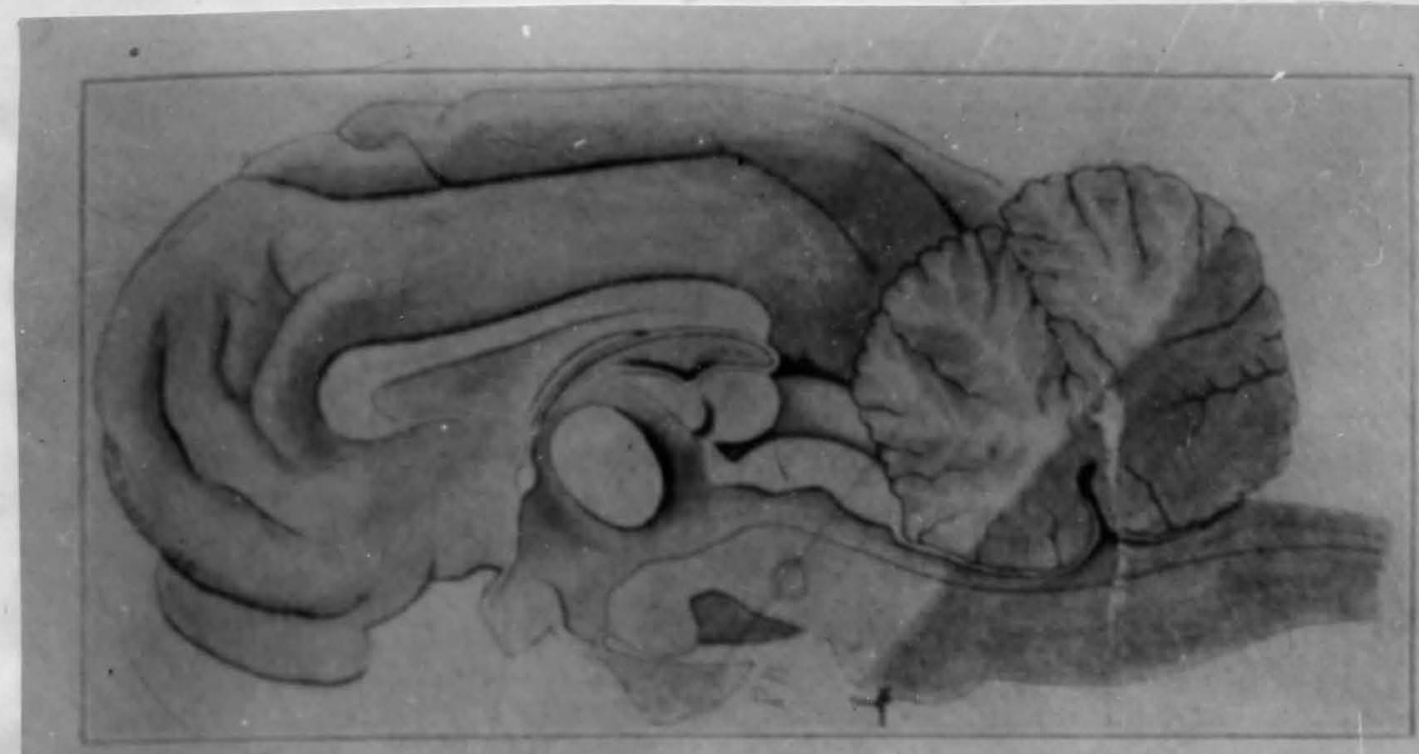

Fig. 3.-Drawing of the medial aspect of the cat's brain showing the basilar artery ligated and the extent of the vital stain over the inferior half of the the cerelellum, the caudal half of the pons, the medulla and the spinal cord.

\section{Figure 2.}

(Taken from Pollock and Davis) Shows relative areas supplied by vertebral circulal6tion and carotid circulation after the basilar artery is ligated at level of fifth nerve.

The jackets used are similar to those described by Kahn $17^{\circ}$ We found it to advantage to move the slot towerd the inflow and outflow tubes, also to slant these tubes on the jackets used for the vertebral arteries. (See Figure 3.) 


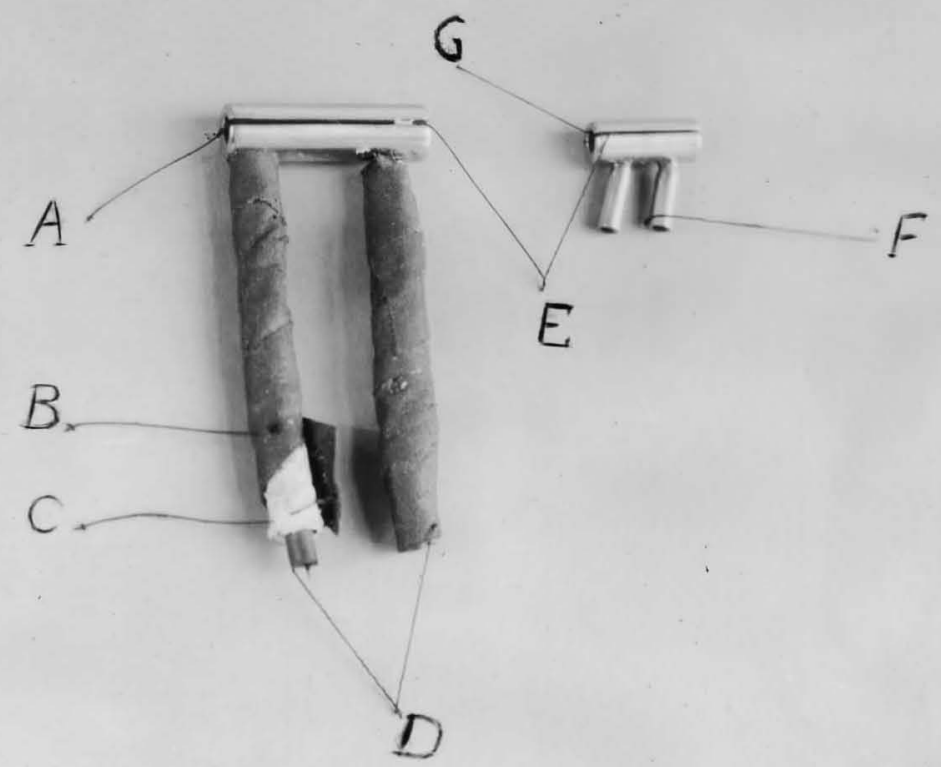

Legend:-

Water jackets for carotid and vertebral arteries. A. and G. - lumens thru which vessels pass.

E. - slots. B. - tape. C. - Asbestos for insulation.

D. - rubber tubing. F. - Slanted metal tubing on vertebral jacket.

The $r$ esevoirs for hot and cold water were made from five gallon bottles placed in barrels with sawdust about them. Temperature can be maintained fairly constantly in this way. Small thermometers were fltted into the inflow tube and outflow tube on the carotid and vertebral systems. Thus the temperature of the inflow and the loss or gain in temperature can be determined from outflow thermometer. The quanity of water passing thru each can be measured and amount of heat gained or lost can be estimated for each system. Ordinary rectal thermometers were used.to take rectal and vaginal temperatures. Skin temperature was taken 
with a thermocouple. Respiratory tracings were made thruout the observations.

When ready to study, the animal is placed on a well padded table and ma comfortable but not restricted or covered. No narcotics or hypnotics are used. Water at various degrees of temperature is pased thruthe carotid jackets at the same time or independently of, water at various temperatures passing thru the vertebral system.

The possibilities are: (I) The carotid system may be heated alone. (2) The carotid system may be cooled alone. (3) and (4) The vertebral system may be heated or cooled alono. (5) The carotid system may be cooled and the vertebral system beated simultaneously. (6) The carotid system may be heated and the vertebral system cooled simultaneously. Of course both may be heated or cooled at the same time. Regardiess of the combination used, the skin temperature is recorded, also the rectal or vaginal temperature, respiratory tracing made, evidence of muscle tone noted, and temperature of inflow and outflow of wat er kept. 
RESULTS 


\section{RESULTS}

Results of observations upon normal dogs and those having the basilar artery occluded are presented in tabular and graphic form.

Table 1

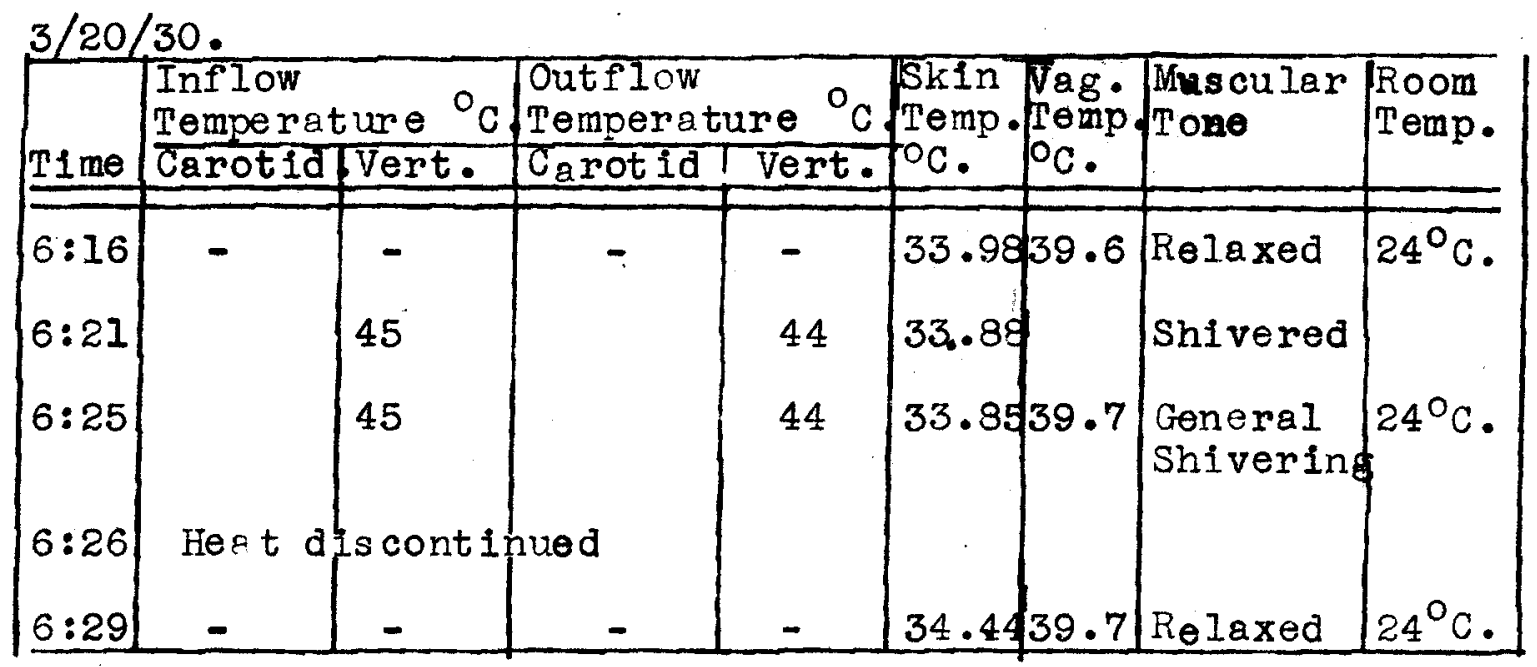

Thermal influences upon the C.N.S.; showing changes in skin temperature, body temperature, and muscular tone. No hypnotics or narcotics. Both external carotid arteries ligated. Basilar artery occluded.

When the vertebral blood is cooled, vaso-dilatation occurs and the skin temperature rises, while the body tempera_ture falls. These two actions are augmonted by heating the carotid blood. Conversely, cooling the carotid blood causes vaso-constriction and a fall in skin temperature and a rise in body temperature. Heating the vertebral blood augments the action of cooling the carotid blood. These facts are 11lustrated in Figure 4.

In Table 1. It may be observed that shivering occurs when the vertebral blood is heated. There is an a sociated vaso-constriction and a rise of vaginal temperature. 


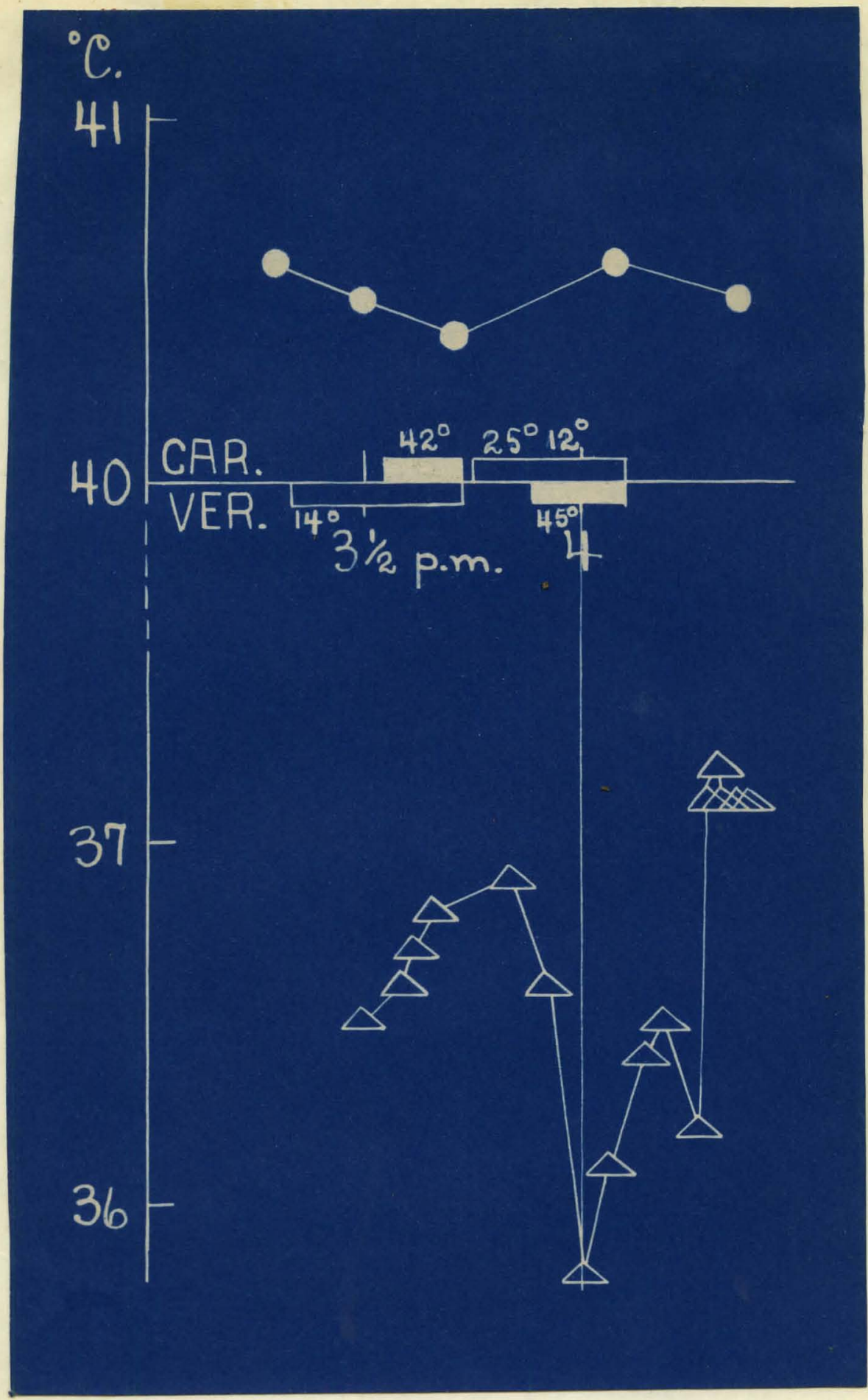

Legend : -

\section{Figure 4.}

Effects of temperature upon the medullo-pontine region and upon the mid brain and telencephalon separately and simultaneously. Bars represent heating, and rectangular outline represents cooling; ordinates: ${ }^{\circ} \mathrm{C} . ;$ abscissae: time; triangles: skin temperature; large dots: vaginal or rectal temperature in ${ }^{\circ} \mathrm{C}$. 
Table 2 .

\begin{tabular}{|c|c|c|c|c|c|c|c|c|}
\hline IIme & $\begin{array}{l}\text { Inflow } \\
\text { Tempera } \\
\text { Carotid }\end{array}$ & $\begin{array}{l}\text { ure }{ }^{\circ} \mathrm{C} \\
\text { Vert. }\end{array}$ & $\begin{array}{l}\text { Outflow } \\
\text { Tempera } \\
\text { Carotid }\end{array}$ & ure ${ }^{\circ} \mathrm{C}$ & $\begin{array}{l}\text { Skin } \\
\text { Temp } \\
\text { oc. }\end{array}$ & $\begin{array}{l}\text { Rect } \\
\text { Temp } \\
\text { C C. } \\
\end{array}$ & $\begin{array}{l}\text { Respira- } \\
\text { ion. }\end{array}$ & $\begin{array}{l}\text { Room } \\
\text { Temp. }\end{array}$ \\
\hline $5: 57$ & - & - & - & - & 37. & 38.9 & 48 & $25^{\circ} \mathrm{C}$. \\
\hline $6: 05$ & - & - & - & - & 36.4 & 39.2 & & \\
\hline $6: 15$ & 55 & 28 & 48 & 29 & Star & ed & & \\
\hline $6: 21$ & & & & & & 39.1 & & \\
\hline $6: 26$ & 54 & 20.5 & 47 & 23 & 37 & & 60 & \\
\hline $6: 30$ & - & - & - & - & 37.4 & & & \\
\hline $6: 37$ & $\begin{array}{c}53 \\
1500 \mathrm{cc}\end{array}$ & $\begin{array}{l}17.5 \\
1300 \mathrm{c}\end{array}$ & 43 & 19 & - & 39. & 60 & $25^{\circ} \mathrm{C}$. \\
\hline $6: 42$ & & 58 & & 58 & & 39 & Periodic & $25^{\circ} \mathrm{C}$. \\
\hline $6: 50$ & & 58 & & 58 & & 39.4 & Periodic & \\
\hline $6: 52$ & & 58 & & 58 & & 39.6 & Periodic & \\
\hline$*$ To & tal flow & & & & & & & \\
\hline
\end{tabular}

Typical results of temperature influences by way of carotid and vertebral blood; showing skin temperature, body temperature, and respiratory changes. Basliar artery occluded.

Simultaneous heating of the carotid blood and cooling of the vertebral blood, as again shown in Pigure $\mathbf{s}$, causes a vaso-dilatation with a rise of skin temperature and a fall of body temperature. Immediate heating of the vertebral blood causes a marked rise in body temperature which continues to rise after heat is discontinued below and the carotid blood cooled. 13,500 calories of heat were introduced by the hot water thru the carotid blood, and only 2,080 calories were removed by means of the cold jackets about the vertebral arteries, yet the body temperature was diminished. This illustrates the thermostatic control exerted by the upper region. 


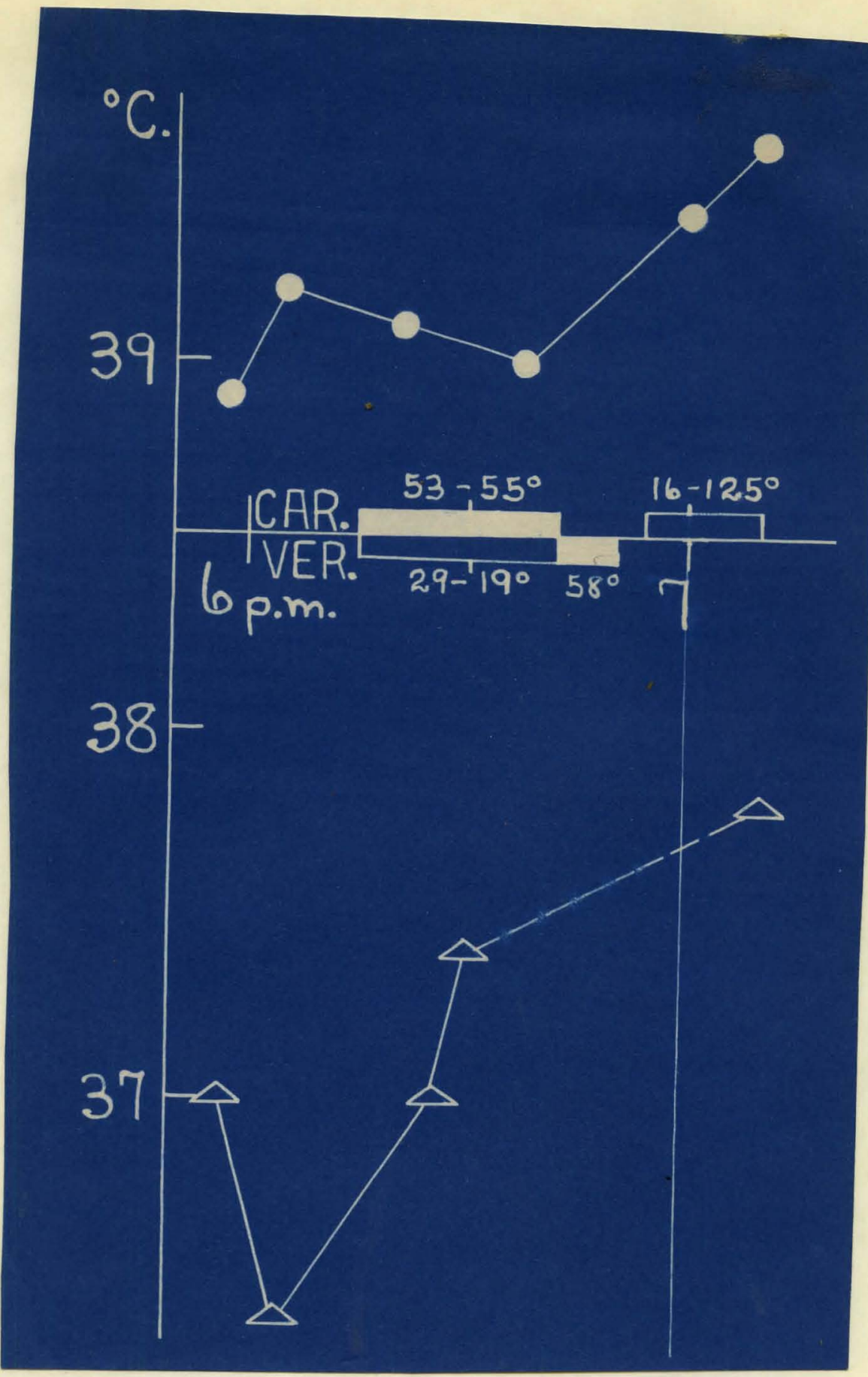

Fi gure 5 .

Legend:-

Same as Figure 4. (See Table 2.) 
Table 3 .

\begin{tabular}{|c|c|c|c|c|c|c|}
\hline PIme & $\begin{array}{l}\text { Inflow } \\
\text { Temperat } \\
\text { Cerotid }\end{array}$ & $\begin{array}{l}\text { ure }{ }^{\circ} \mathrm{C} . \\
\text { Vert. }\end{array}$ & $\begin{array}{l}\text { Skin } \\
\text { Temp. } \\
\text { o. }\end{array}$ & $\begin{array}{l}\text { Vag. } \\
\text { Temp. } \\
\text { Oom. }_{\text {C. }}\end{array}$ & Respiration & $\begin{array}{l}\text { Room } \\
\text { Temperature }\end{array}$ \\
\hline $3: 40$ & - & - & 38 & $40 \cdot 5$ & 28 & $26^{\circ} \mathrm{C}$ \\
\hline $3: 45$ & - & - & 38 & 40.5 & 28 & \\
\hline $3: 52$ & - & 6 & - & - & - & - \\
\hline $3: 57$ & - & 6 & 38.8 & .40 .4 & 22 & $26^{\circ} \mathrm{C}$ \\
\hline $4: 00$ & - & 6 & - & 40.4 & 22 & - \\
\hline $4: 11$ & & Off & 38.1 & 40.4 & - & \\
\hline $5: 12$ & - & - & 38.2 & 40.5 & 44 & $26^{\circ} \mathrm{C}$ \\
\hline $5: 14$ & 46 & 9 & -Star & ted & & - \\
\hline $5: 19$ & 46 & 8 & 38.8 & 40.4 & $\begin{array}{c}32 \\
\text { Shallow }\end{array}$ & \\
\hline $5: 24$ & 48 & 7 & - & 40.3 & . & \\
\hline $5: 33$ & 47 & 9 & 38.2 & 40.1 & & \\
\hline $5: 43$ & 46 & 9 & 38.0 & 40.1 & & \\
\hline $5: 45$ & Off & Off & & 40.1 & & \\
\hline $5: 51$ & & 49 & & $40 \cdot 2$ & 60 & $26^{\circ} \mathrm{C}$. \\
\hline $5: 56$ & & $\begin{array}{l}49 \\
\text { Off }\end{array}$ & , & 40.1 & Ween & \\
\hline $6: 02$ & 10 & & 38 & 40 & & \\
\hline $6: 08$ & 8. & & 37.2 & 40.1 & $\begin{array}{r}32 \\
\text { Deep }\end{array}$ & $26^{\circ} \mathrm{C}$ \\
\hline
\end{tabular}

Separate and simultaneous temperature influences carried by carotid and vertebral blood. Basilar artery occluded.

In Table 3. and Fipure 6. it will be observed that cooling the vertebral blood causes a vaso-dilatation and a sharp rise in skin temperature. There is a slight fall in body temperature. Cooling the vertebral blood reënforced by 
heating the carotid blood gives a temporary vaso-dilatation, the skin temperature however returning to normal before the thermal influences were discontinued. Heating the vertebrals and cooling the carotid blood causes a characteristic fall in skin temperature. The body temperature changes to a less marked degree.

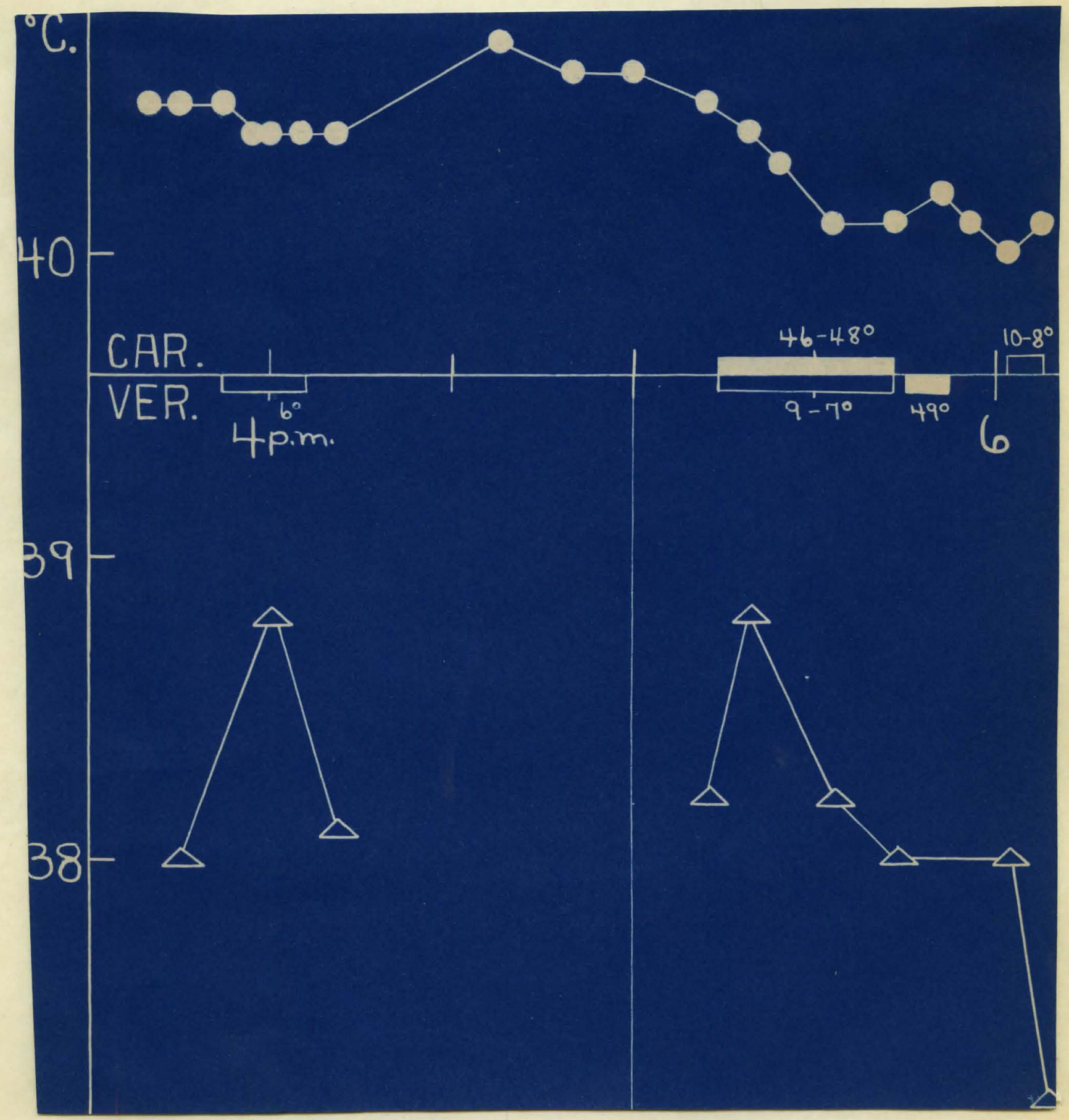




\section{Table 4.}

$2 / 22 / 30$

\begin{tabular}{|c|c|c|c|c|c|c|c|c|}
\hline $\operatorname{Tim} \theta$ & $\begin{array}{l}\text { Inflow } \\
\text { Temperat } \\
\text { Carotid }\end{array}$ & ture ${ }^{\circ} \mathrm{C}$. & $\begin{array}{l}\text { Outflow } \\
\text { Tempera } \\
\text { Carot } 1 \text { d }\end{array}$ & Vure ${ }^{0} \mathrm{C}$ & $\begin{array}{l}\text { Skin } \\
\text { Pemp. } \\
\rho_{C} .\end{array}$ & $\begin{array}{l}\text { Vag. } \\
\text { Temp } \\
\text { OC. }\end{array}$ & $\left\{\begin{array}{l}\text { Respira } \\
\text { tion. }\end{array}\right.$ & $\begin{array}{l}\text { Room } \\
\text { Temp. }\end{array}$ \\
\hline $3: 38$ & - & - & - & - & 33.9 & 39.6 & 28 & 25.3 \\
\hline $9: 57$ & - & - & - & - & & 39.6 & & \\
\hline $10: 02$ & - & 10.7 & & $22 \cdot 2$ & & & & \\
\hline $10: 16$ & & 10 & & 20 & & 39.6 & $\begin{array}{l}\text { Slower } \\
\text { Shallow }\end{array}$ & \\
\hline $10: 20$ & & Off & & Off & & & & \\
\hline $10: 35$ & & 40 & & 23 & & 39.6 & & \\
\hline $10: 44$ & & 45 & & 24 & & 39.5 & & \\
\hline $10: 59$ & & 47 & & 25 & & 39.5 & & \\
\hline $11: 00$ & & 43 & & 22 & & 39.5 & & \\
\hline $11: 07$ & & 45 & & 29 & & 39.4 & & 25.3 \\
\hline $11: 11$ & & Off & & Off & & & & \\
\hline $11: 26$ & & - & & & 34.8 & & & \\
\hline $11: 28$ & & 40 & & 28 & 35. & 39.4 & & \\
\hline $11: 29$ & & 41 & & 30 & & & & \\
\hline $11: 32$ & & 43 & & 32 & 33.5 & 39.4 & & \\
\hline $11 ; 44$ & & 43 & & 33 & 33.8 & 39.4 & $\begin{array}{l}\text { Hyper- } \\
\text { pnea. }\end{array}$ & 25.3 \\
\hline $11: 55$ & . & 42 & & 33 & 34.3 & 39.6 & & \\
\hline $11: 56$ & & off & & off & & & $\begin{array}{l}\text { Dimin- } \\
\text { jshed }\end{array}$ & \\
\hline $12: 00$ & 43 & & 30 & & & & & \\
\hline $12: 12$ & 43 & & 32 & & 34.6 & & & \\
\hline $12: 13$ & 44 & & 38 & & & 39.6 & & \\
\hline $\begin{array}{l}12: 177 \\
12: 19 \\
12: 94\end{array}$ & $\begin{array}{c}44 \\
44 \\
44\end{array}$ & & $\begin{array}{l}42 \\
43 \\
43 \\
\end{array}$ & & $\begin{array}{l}34.9 \\
35 \\
34.7 \\
\end{array}$ & $\begin{array}{l}39.5 \\
39.6 \\
\end{array}$ & & \\
\hline
\end{tabular}

Temperature influences by way of carotid and vertebral blood upon normal dog. (See Figures 7 and 8.) 


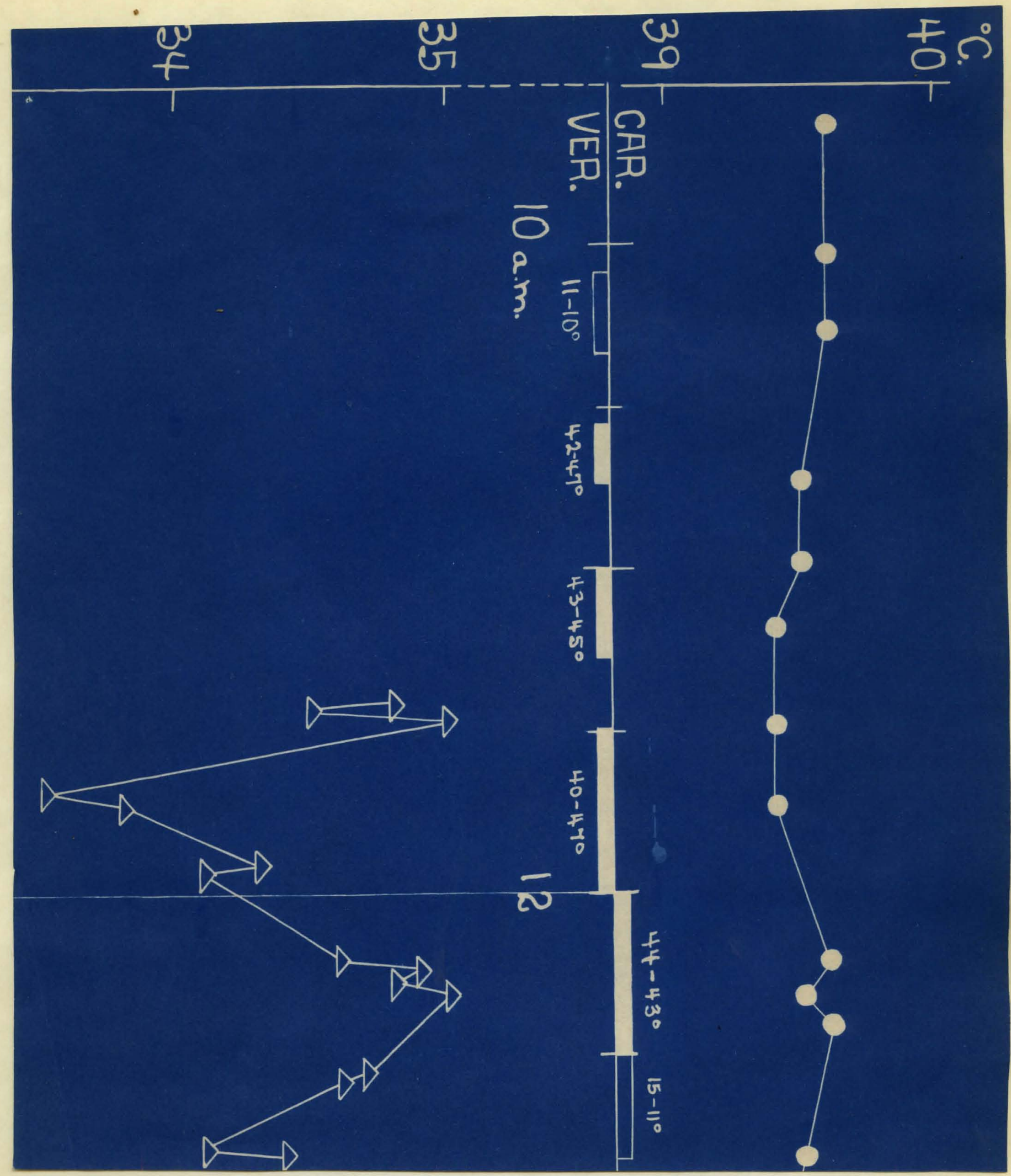

Figure 7 .

Legend : -

Same as Figure 4. (See Tableo 4. and Figure 8.) 
Arimals in which the basilar artery has not been clipped react somewhat differently to temperature influences as noted in Figure 7 and Table 4. Immediate and temporary vasomot or changes with corresponding skin temperature variations occur as in animal with the basilar artery ligation. The body temperature changes little. A given temperature has opposing influences when allowed to affect the two portions of the brain simultaneously.

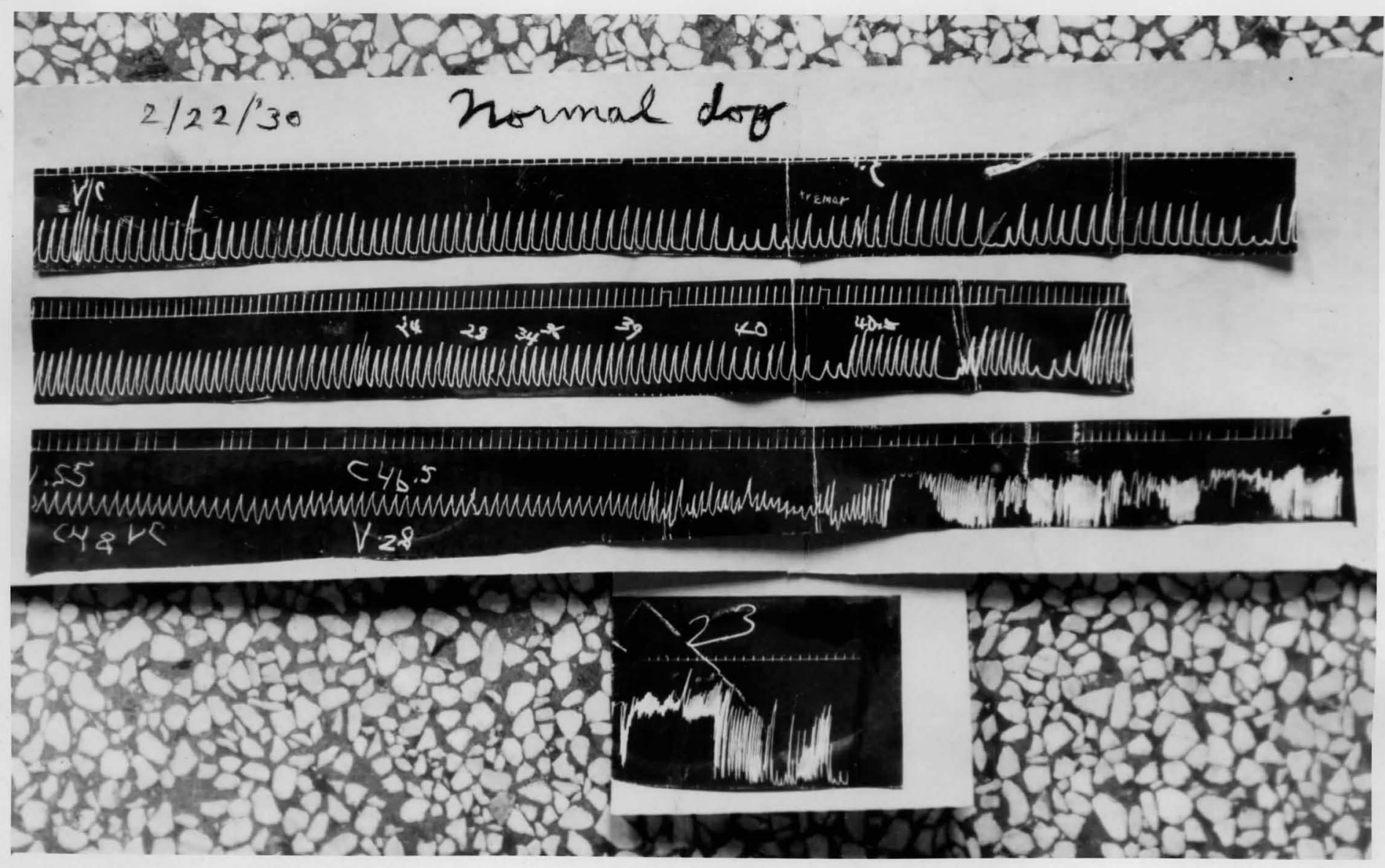

Legend : -

$$
\text { Figure } 8 .
$$

normal dog.

Temperature influences upon respiration in a

A respiratory tracing from a normal dog is shown in figure 8. At first the vertebral blood is cooled with a 
resulting inhibition of the respiratory center. Respirations are slowed and diminished. As the temperature influences approximate body temperature, respiration returns to normal, but when they rise to 40 or above respiration becomes markedly increased in rate and depth. Feriodicity results, as often occurs in such cases. Heating the carotid blood stimulates the upper inhibitory mechanism and respiration becomes slow as when the medullo-pontine region was cooled. However, as the basilar artery was not ligated the heat spreads to the respiratory center below and typical periodic breathirg is recorded. In the animals with the basilar artery occluded, no such evidence of spread of thermal influences was secured. 
DISCUSSION 
DI CUSSION

The centra]. application of temperature separately to the two regions of the brain appears to help in the localization of function. The vasomotor results of the thermal treatment of the parts supplied by the vertebral circulation indicate that heat can arouse vasoconstricticn and inclines one strongly to belleve that constrictor influences dominate in the redulzo-pontine region.

To rule out peripheral reflex influences, the external carotid arteries were ligated in one case with no change in the vasomotor resilts.

It may be noted that with the introducticn of heat by the verteiral system to the pons and medulla that respiration increases in both rate and volume. The same thing occurs when cold is introduced by way of carotid blood to the upper region. On the othen hand, cold applied to the medullopontine region slows the respiration and decreases its amplitude. This is tme with heating the upper region. It may also be observed that heat at $43^{\circ} \mathrm{C}$. to $46^{\circ} \mathrm{C}$. by way of the vertebral circulation, a m cold at $8^{\circ} \mathrm{C}$. to $12^{\circ} \mathrm{C}$. introduced above by the carotids, causes periodic respiration; i.e. periods of marked hyperpnea alternating with apnoea. This hyperpnea must le due to the direct stimuletion of the respiratory center by the heat, or in the other case to indirect stimlation by the rolease of inhibitions from above by cold. The respiration probably becomes periodic because the increased ventilation weshes out the $\mathrm{C} \mathrm{O}_{2}$.

$\mathrm{Kahn}_{17}$ was able to produce polypnea when he heated the carotid blood. Moorehouse ${ }_{18}$ used further precautions to protect the vagi and then secured both slow deep respira- 
tion, and a rapid shallow respiration when the carotid blood was heated. In some instances respiration did not change. Moorehouse applied heat however while the animal was under the influence of narcotics and hyonotics. (He found the vasomotor center to be very easily influenced by heating the carotid bloodd

In contrast to others who have heat ed the blood supplying the brain in dogs we have never observed the shallow rapid respiration defined as heat polypnea. When heated, the respiratory center of the medulla evokes an increase in both depth and rate of the respirations, thus affording the additional ventilation needed to support the extra muscular activity. Cooling the carotid has the same effect ( by removing the inhibition exerted by the basal ganglia upon the meduIIo-pontine region). But heating the carotids (Inthe ligated dog, and until the heat spreads in the unligated animal) decreses respiratory rate as well as depth.

Shivering was noted when the upper region was cooled and the lower portion wes heated, separately or simultaneous$1 \mathrm{y} \cdot$

Body temperature indicated by rectal and vaginal temperature, changed with various thermal influences indicating a thermostatic temperature regulating mechanism in the upper portion of the divided brain. For, as has been shown in rabbits by directly heating the base of the brain, carotid heating lowered the rectal temperature and carotid cooling raised 1 t. 
With the idea that heat is a stimulant and cold a depressant to the areas affected, it seems that the following deductions may be arrived at from the above findings.

The vasomotor and respirat ory mechanisms a re aroused by vertebral heating, hence are located in the lower of the two brain portions." Inhiblting influences upon them originate from the upper system. Stimulating or heating the mechanism directly by means of the vertebral blood supply produces vaso-constriction and increased respiration, while cooling this blood causes depression of these mechanisms, giving vaso-dilatation and decreased ventilation. Rogers $_{4}$ caused shivering in pigeons, as others have in rabbits, by applying cold to the thalamus. Our carotid cooling $\left(8^{\circ} \mathrm{C}\right.$. to $15^{\circ} \mathrm{C}$ ) does the sam. Heat by way of the vertebral blood likewise causes shivering with inflow temperatures ranging from $42^{\circ} \mathrm{C}$. to $46^{\circ} \mathrm{C}$. on different anima ls . This would indicate a stimulation of a medullo-pontine mechanism directly by heated blood and that cold above releases the inhibition of the same.

Ab ove, on the inhibition system, stimulation by heat would further inhibit the actions of the lower mechanisms and give the same as cold below, while cold, depressing the inhibition mechanism, would increase the action below and give the same results as direct stimulation.

Inhibitory control by the mesencephalon and the basal ganglia affords a mechanism for body heat regulation; it presides over vasomotor tone, respiration, muscular (and doubtless other metabolic activity). While undoubtedly 
influenced largely by afferent impulses from the skin, our work adds support to the view that the upper central region is airectly influenced by temperature just as is the sensitive element of a thermostat. 
CONCLUSION 
CONCLUSION

1. Heat acts as a stimulant and cold as a depressant to the important brein centers concerned with temperature regulation.

2. Heating the medullo-pontine region alone, causes peripheral veso-constriction, increased muscular action, and often times shivering, Increased ventilation, and a rise in body temperature. Cooling the carotid blood produces simflar responses.

3. Cooling the medullo-pontine region causes vaso-dilatation reripherally; lessens muscular activity, diminishes ventilation and causes a fall in body temoerature. Heating the carotid blood produces similar changes.

4. When both regions are treeted simultaneously with opposing temperature influences, the effects of one are augmented by the other.

5. When both regi ns are treated simultaneously with like temperature influences, (as occurs to some extent when the thermal irfluence is applied to but one of the two arterial systems in dogs with intact basilar arteries) the effects upon one tend to counteract the effects upon the other. 
BIBLIOGRA PHY 


\section{BIBLIOGRA PHY}

1. Barbour, H.G.,Arch.f exper.Path.u.Pham., 1912, IXX, I.

Physiological Reviews Vol.I, No.2,Apr.1921,295.

2. Hashimoto, H., Arch.f .exper.Path.u.Pharm., 1915, IXXVIII, 370.

3. Prince,A.I., and Hahn, I.J., Amer.Journ.Phys1ol ., 1918, XIVI, 412.

4. Rogers, F.T.,Amer.Journ.Physiol., JuIy 1919, Vol.XIIX, No .2, 271.

5. Bazett,H.C., and Penfield, G.,Brain, 1922,XIV,185.

6. Bazett,H.C.,Physiol. Kevlews, Vol.VII, No.4,0ct.1927, 531.

7. Pembrey, M.S., cited by Bazett $6{ }$

8. Leflevre,J., cited by Bazett $6^{\cdot}$

9. Richet, C. (1898) cited by Bazett ${ }_{6}$

10.Heymans, J.T., and Heymans, C.,Am.de la Soc. Scient. de Bruxelles, 1926, XLVI, 294.

11. Sherrington, C.S., Journal of Physiol.Vol.IVIII, No.6, May 23, 1924-26. 12. Is enschmid, V.K.and KrehI,I.,Arch.f.exper.Path.u.Pharm.,1012, IXX, 109.

13.Ieschke, E., Zeitschr .f exper.Path.u. Therap.1813,XIV, 167 . 14.Isenschmid,V.P.and Schnitzler,W.,Arch.f exper.Pathl.u.Pharm., 1914, IXVI,202.

15. Baronne, J.G., Dusser de.,Arch. Nelerland de Phys1ol. de Ihomme et des a nimaux, 1919, IV, 31 .

16.Pollock,I.J. and Davis,I.E.,Arch. Ieurol.Psych.1923,Vol.X,391. 17.Kahn, R.H.,Arch.f Physiol., (Engelmann) 1904,Suppl.81. 18. Moorehouse, V.H.H., Ame r.Journ.Phys iol.1911, Vol .28, 223. 